\title{
An Analysis of The Need for The Necessity of Mathemathics Learning Model Based on Scientific Approach at Elementary School
}

\author{
Rahmat Fajar Prakoso \\ Departement of Master's Primary \\ Teacher Education \\ Sebelas Maret University \\ Surakarta, Indonesia \\ fajarahmat.prakoso@gmail.com
}

\author{
St. Y. Slamet \\ Departement of Primary Teacher \\ Education \\ Sebelas Maret University \\ Surakarta, Indonesia \\ slametsty@yahoo.co.id
}

\author{
Budi Usodo \\ Departement of Mathematics \\ Teacher Education \\ Sebelas Maret University \\ Surakarta, Indonesia \\ budi_usodo@yahoo.com
}

\begin{abstract}
This study aim to describe the existence of mathematics learning and analyze the need for the necessity of mathematics learning model based on scientific approach for the $5^{\text {th }}$ grade students of elementary school in Surakarta. Method applied in this study was descriptive qualitative and quantitative research design. The sample data was obtained by using purposive sampling technique. Samples taken for this study consisted of 107 students and 4 teachers. The qualitative data collections technique was conducted by using interview, observation, and document analysis, whereas, the quantitative data was conducted by using questionnaire. Interactive analysis was used to analyze the data that have been collected. The aspects being measured were the teachers and students responses toward mathematics learning activities, the availability and supports of mathematics learning model that can improve either the problem solving abilities, or the interests into mathematics learning model based on scientific approach. The results indicated that (1) teachers are considered still use the traditional learning model; (2) there are a lot of limitations in the traditional learning model; (3) teachers and students need of mathematics learning model can improve the problemsolving abilities. Thus, it is necessary to develop the mathematics learning model based on scientific approach.
\end{abstract}

Keywords-scientific approach; problem solving; mathematics; elementary school

\section{INTRODUCTION}

Educational challenges of the 21st century as it is today is to prepare human resources in order to have the ability to communicate and mastery of science technology through the learning process. Directorate General of Primary and Secondary Education in the Implementation Guide of proficiency in the $21^{\text {st }}$ Century also confirmed that the competence of $21^{\text {st }}$ century skills or proficiency include 1) the critical thinking skills and problem solving, 2) ccommunication skills, 3) creativity and innovation, 4) ccollaboration [1]. The fourth skill or ability of learners are nurtured and developed in each subject. Mathematics as one of the subjects has played role to develop the critical thinking skills and problem solving. This is due to the study of mathematics requires thinking to find ways in determining solutions to problems.

Problems in mathematical learning that occur nowadays is concerning to the abstract nature of mathematics learning, so that learners are difficult to understand. Therefore, it gives impact to the students' lack of interest in math and critical thinking that they are not capable to learn mathematics. Shadiq and Mustajab argued that, some students think that they do not have the talent to learn mathematics [2]. This means that they have already sentenced themselves to not be able to learn math, even if they study the mathematics, they will fail to learn it. It was very influential on student achievement in math. The indicator can be seen from the research conducted by the Program for International Student Assessment (PISA) 2015 in www.pisa.oecd.org which showed that the average score of mathematics in Indonesia is 386. The mathematics score is considered still far from the average score issued by PISA which is 490 , Therefore, by those score, Indonesia is in the $63^{\text {rd }}$ position out of the 69 countries evaluated [3]. The results of the PISA studies showed that most students in Indonesia are still difficult to grasp the concepts of mathematics learning materials.

One of the students' competence elusive but many appear in everyday life is a mathematical problem-solving ability. Problem-solving skills have more difficulty levels in mathematics as it is necessary to understand and planting a powerful concept so that learners can solve mathematical problems. According to Lechner in Wardhani stated that solving the problem is the process of applying the previously obtained knowledge into the new situations that have not been recognized yet. In line with the opinions of Lechner, Harris www.vitualsalt.com web site stated that solving the problem is "the management of a problem in a way that successfully meets the goals established for treating it" [4]. 
This means that solving the problem is the management problem in a way that managed to find the desired destination. The problem management is done by linking the basic concepts unfamiliar with the situation in order to find the desired destination. Due to the process of associating the concept with a new situation, learners are generally experiencing some obstacles.

Based on the interviews conducted with few teachers, students of elementary schools having low ability to solve mathematical problems. Students are not given chances to develop their reasoning in solving problem through a variety of ways. Therefore, it effects the dependence of students to teachers in solving the problems. Tarhan et., all said "creative thinking is problem solving from a different sense. Because there is a problem as the problem cannot be solved by conventional means. Its solution requires creating new ways, or divergent thinking and side thinking" [5]. Dependence arising from learning students who are still using the traditional method with the dominant role of the teacher in explaining the material to the students. Therefore, there is need for a way to create learning mathematics that focuses on the process, so that the process is embedded knowledge of mathematics.

Learning which focuses on the process can be created through the application of learning models, one with a cooperative learning model of Group Investigation. Basically, learning model Group Investigation adopt the model prevailing in society, about how members of society make the process of social mechanisms through a series of social agreement [6]. Aksoy \& Gurbuz argued, "This method (Group Invetigation) will be beneficial for the academic achievement of the students and it will a make students more active in lessons" [7]. Furthermore, Permendikbud No. 103 of 2014 states that the scientific approach is based on the approach to the scientific process.

Based on the above, in order to develop the necessary problem-solving ability of learning that focuses on the process and student-centered. Learning can be created through the Group Investigation learning model in which there are aspects of the Scientific Approach. Therefore, research analysis aims to analyze the response of teachers and students to the needs of Cooperative Learning Model type Group Investigation based on Scientific Approach.

The purpose of this study was to describe the state of learning and analyzing the need for the necessity of mathematics learning model based on Scientific Approach by the aspects of mathematics learning conditions, availability of model of learning that can develop students' problem-solving abilities, and interest in the cooperative learning model type Group Investigation based on Scientific Approach.

\section{RESEARCH METHODS}

This type of research is descriptive research that is used to describe the state of teaching and analyze the necessity of mathematics learning model based on scientific approach for elementary school of the fifth grade students. Sukardi argued descriptive study aims to systematically describe the facts and characteristics of the object under study accurately [8],

Implementation of the field study, the sample taken by using purposive sampling. The subject of this study were students and teacher of the fifth grade of four elementary schools in Surakarta, with the total number population of 107 students and 4 teachers.

Sources of data in this study were teachers and students, events, and documents. Data were collected through interviews, observations, and analysis of documents, as well as questionnaires. Measurement data on the validity of this research was done through triangulation, and inspection peers through discussion. Furthermore, the data were analyzed using interactive analysis techniques disclosed by Miles and Huberman namely: data collection, data condensation, a data display, and conclusion [9].

\section{Result AND Discussion}

In this section, will put forward a description and analysis of data on the needs of mathematics learning model based scientific approach on elementary school fifth grade students. The results obtained in this study, can generally be described as follows: (1) learning is still centered on the teacher; (2) there are limitations in mathematical learning model which is commonly used; (3) teachers and students in need of math learning model that can foster students' ability to solve problems. Data collection techniques in this study with interviews, observation, analysis of documents, and questionnaires.

Interviews were conducted toward the fifth grade of elementary school teacher in Surakarta. Based on the results of these interviews obtained information that in general teachers are not satisfied with the mathematical problem solving ability in students, because students have difficulty working on mathematical problems. Mathematics learning activities are conducted with teachers lecturing and then proceed with the exercises. If identified, the learning pattern is still the conventional or traditional. In the learning process, teachers have not been able to create an atmosphere of active learning in the classroom. The learning environment will encourage active students discover and cultivate their own knowledge obtained by the students. The fact that there is in the field, students receive only what is described by the teacher through a lecture so that students are also easy to forget the material that has been submitted by teachers. It means that teachers are dominant in delivering learning in the classroom, so students only pay attention to the notes based on the teacher's explanation. In the opinion of Aisyah, learning must be centered on student learning activities and not centered on the activities of teachers teaching [10]. Therefore, the essence of mathematics learning should be directed and designed with the goal of creating a learning environment that provides opportunities for students to work and gain experience of learning is also used mathematical knowing. Learning resources are limited to the issue of textbooks nationwide. In 
addition, the application of the learning model that develops reasoning mathematics students to the subject matter has not been made in the study of mathematics.

Other data collected through observation of current mathematics learning activities take place. Based on observation, according to the findings at the time of the interviews with teachers, learning is still dominated by teachers, learning resources are also still fixated on textbooks, the media used is still limited in the classroom. This resulted in students not been actively involved in learning. Therefore, it takes a learning model that can develop reasoning power of students to the mathematical material and encourage active students.

Questionnaires given to students and teachers of the fifth grade of primary school. The questionnaire contains questions related to the study of mathematics. Furthermore, the results of questionnaires answered by students and teachers is a response to the learning of mathematics that has been done so far. The result of the calculation of the questionnaire responses of students and teachers can be seen in Figure 1 and Figure 2 below.

\section{Student's Responds to The Need of Mathematics} Learning Model Based on Scientific Approach

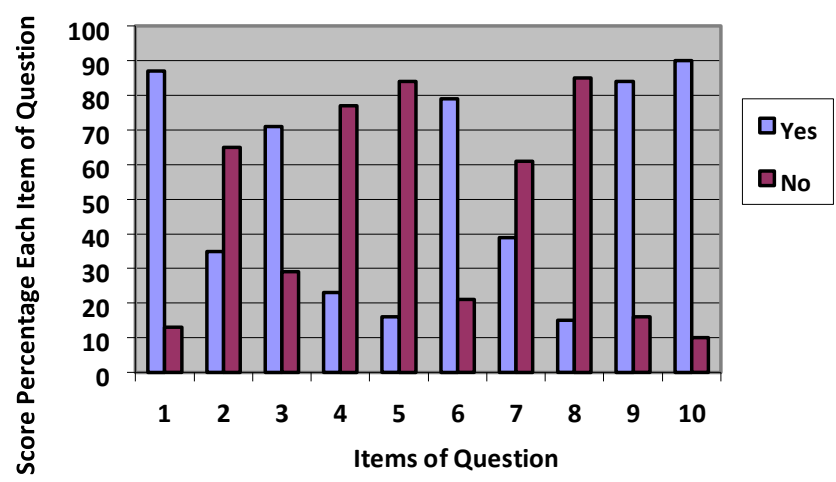

Fig. 1. student's responses to the needs of mathematics learning model based on Scientific Approach

Fig. 1. shows the implementation of the learning of mathematics in primary schools are still not optimal, especially on competence development in students solve problems. Aspects of mathematics learning conditions, in particular on the competence of solving mathematical problems contained in the item questions 1,2 , and 3 . On the question item number 1 indicates that there are $87 \%$ of students stated learning of mathematics delivered by teachers' notes. Based on the item question number 2 are $35 \%$ of students stated learning about mathematical problem solving using special ways. Specific ways that meant, among other models, strategies, methods, and media that support the learning of mathematics. It has an impact on students' mathematical problem solving abilities, shown on item

Question 3. It points out that there are $71 \%$ of students who have difficulty in solving mathematical word problems. In other words, the ability of students to solve mathematical problems low evidenced from the large number of students who still have trouble identifying the question of mathematical problem. Peker \& Mirasyedioglu stated that, “ Due to the implementation of traditional instruction, many students find it difficult, to adapt to learning environments that, in some situations, have conflicted with the students' values, attitude, and belief systems" [11].

Aspects of the limitations of the learning model commonly used in mathematics, particularly on the competence of solving mathematical problems contained in the question item number 4,5 , and 6 . Item question number 4 shows that $23 \%$ of students declared able to understand the mathematical material using learning patterns used by teachers during this. Item question number 5 indicates that there are $16 \%$ of students who feel they have the ease in understanding the problem solving using the learning pattern is used for this. Furthermore, on the question item number 6 indicates that there are $79 \%$ of student interest in mathematics, particularly in problem solving competence. Facts on the ground indicate that students have an interest in studying mathematics, but the pattern of learning that is used can not lead students to understand the concept of material embedded in the learning of mathematics.

Aspects needs cooperative learning model of Group Investigation outlined scientific approach based on item Question 7, 8, 9, and 10. Question number 7 shows that 39\% of students ever flocking in mathematics. This indicates that there is still sparse learning by utilizing the interaction of group work, especially in mathematics. Item question number 8 shows that $15 \%$ of students accustomed to doing the stages of identification math problems based on the scientific approach. Item question number 9 states that $84 \%$ of students in need of special learning model to develop mathematical problem solving ability. Furthermore, students' response to the development of effective learning pattern develops mathematical problem solving abilities are shown on the item question number 10, with a percentage of $90 \%$ of students want an effective new learning patterns and fun.

Teacher's Responds to The Need of Mathematics Learning Model Based on Scientific Approach

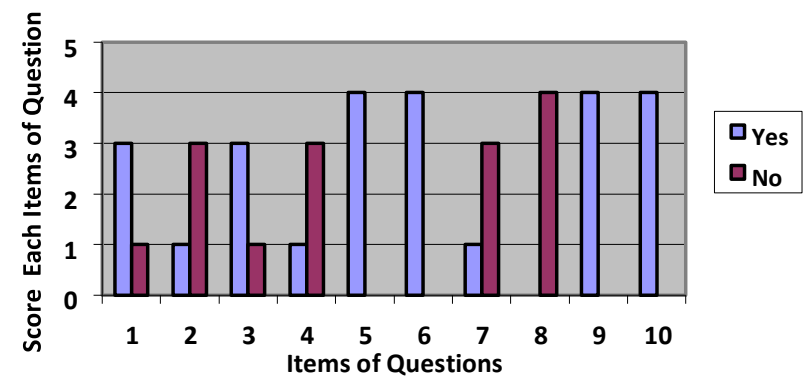

Fig. 2. teacher's responses to the needs of mathematics learning model based on Scientific Approach 
Fig. 2. shows the teacher's response to a questionnaire about the needs of mathematics learning models given to them. The questions were given as many as 10 items. Aspects of mathematics learning conditions, in particular on the competence of solving mathematical problems contained in the item questions 1,2 , and 3 . Item questions 1 states that there are three of four teachers who administered a questionnaire using conventional or traditional learning patterns namely with a lecture and exercises. Information from the inquiry item number 2 there is one teacher who uses the innovative learning model, strategies, and methods for developing a mathematical problem-solving ability. On the question item number 3 indicates that 3 out of 4 teachers who asked for information have difficulty in teaching mathematics materials on the competence of solving problems.

The results of the questionnaire to the teacher goes on to explain the limitations of the learning model commonly used in mathematics, particularly on the competence of solving mathematical problems contained in the question item number 4,5 , and 6 . Item question number 4 states that there is only 1 of 4 teachers use instructional media which can develop mathematical problem solving ability. The results of the questionnaire on question number 5 was found information that four teachers have difficulty in developing math learning. The difficulties have an impact on the ability of mathematical problem solving, it can be seen from the question item number 6 which states there are 4 teachers agree that the difficulties in developing a learning affects students' problem-solving abilities.

Information about the needs of cooperative learning model of Group Investigation scientific approaches are based on item Question 7, 8, 9, and 10. Question number 7 states that 1 out of 4 teachers to condition students in groups to teach math material. The next item is question number 8 shows that of the four teachers who take no information that teaches scientific stages in solving mathematical word problems. Item question number 9 states 4 teachers require special learning model to develop mathematical problem solving ability. Item question number 4 teachers agree stating that if the developed pattern of effective mathematics learning and fun.

Seeing the state in some primary schools in Surakarta learning patterns are still traditional, with a lecture and exercises it is necessary to develop a model of learning that reasoning power of students' learning materials. The findings of the data collection such as interviews, observation, analysis of documents and questionnaires also give the same

\section{CONCLUSION}

Based on the analysis of research and discussion can be concluded that the study of mathematics is still conventional or traditional. Learning to use the lecture method with exercises. The results of the needs analysis showed that (1) the learning is centered on the teacher; (2) there are limitations in mathematical learning model commonly used; picture of the learning of mathematics today. The learning model as a framework in the learning activities to be the solution to develop an active and effective learning. According Suprijono learning model is a pattern that is used as a guide in the learning in the classroom and tutorial [12].

Selection of appropriate learning model also affects the success in learning. One model of learning that can be developed is cooperative learning model type Group Investigation. Kurniasih \& Sani found Group Investigation model is one of the cooperative learning model that has a pressure point on the participation and activity of the students to find their own material or anything about the subject matter to be studied [13]. Searching information by self in this model through social interaction in group. The process of this social mechanism appeared in six stages of implementation that is, selecting topics, designing cooperation within the group, the implementation of the investigation, planning presentation, make presentations, and an evaluation [14]. Karafkan and Aghazadeh stated, "One of the crucial differences between individuals is that some of the learners desire to learn in social situations. All learners need to know how to promote in such situations and cooperative learning Provides opportunities to promote and practice the strategies they need to work with others" [15]. The model is consistent with the theory of constructivism learning, Suprijono stressed about Social Constructivism Vygotsky theory that knowledge is built and constructed to the mutual involvement of other people (interaction) opens an opportunity for them to evaluate and improve the understanding [12].

According to research by Retno explained that the advantages of applying the learning model of Group Investigation in these studies is trained students to socialize, solve problems, and students are more able to construct understanding of the concept of matter [16]. On the other hand, Kurniasih and Sani argues weakness of Group Investigation learning model is complex and difficult to implement in the learning [13].

Development undertaken aimed at eliminating weaknesses in the model Group Investigationso that the model is effective to improve the ability of mathematical problem solving. The development is carried out by incorporating elements of scientific approaches in the learning model of Group Investigation. Hosnan explained that the study results with the scientific approach make learners more productive, creative, innovative, and affective through the strengthening of attitudes, skills and knowledge are integrated [17].

(3) teachers and students in need of math learning model that can foster students' ability to solve problems. Based on the above results, there are some suggestions that can convey the researchers need to develop a cooperative learning model type Group Investigation were developed according to aspects of the scientific approach. The existence of such development will help students and teachers in the learning process of mathematics. It further will result in increased ability to solve mathematical problems in students. 


\section{ACKNOWLEDGMENT}

The authors thank the teachers and students who have participated in the research so that research can be done well, smoothly and successfully.

\section{REFERENCES}

[1] No name, "Panduan Implementasi Kecakapan Abad 21", Jakarta: Ditjen Pendidikan Dasar dan Menengah, 2017, pp. 6-7.

[2] Shadiq and Mustajab, Penerapan Teori Belajar dalam Pembelajaran Matematika di SD, Yogyakarta: PPPPTK Matematika, 2011, pp. 1-2.

[3] PISA, Programme for International Student Assessment 2015 Result in Focus, Downloaded on July 312017 at 13.46 from www.oecd.org

[4] Wardhani. S, et. all, Pembelajaran Kemampuan Pemecahan Masalah Matematika di SD. Yogyakarta: PPPPTK Matematika, 2010, pp. 15

[5] T. Sinem et. all, Quadruple Thinking: Creative Thinking. Journal Social and Behavioral Sciences, 2011, 12 pp. 536-544

[6] M. S. Sutikno, Metode \& Model-model Pembelajaran Menjadika Proses Pembelajaran Lebih Aktif. Lombok: Holistica, 2014, pp. 78 79.

[7] Aksoy and Gurbuz, Group Investigation Teaching Technique In Turkish Primary Science Courses, 2013, Vol. 21 no 10.

[8] Sukardi, Metodologi Penelitian Pendidikan: Kompetensi dan Praktiknya, Jakarta: Bumi Aksara, 2011.

[9] M. B. Miles and A. M. Huberman, Analisis Data Kualitatif, Jakarta: UI-Press, 2009, pp. 14-15.

[10] N. Aisyah, ett. All, Pengembangan Pembelajaran Matematika SD, Jakarta: Depdiknas, 2007, pp. 4

[11] Peker. M \& Mirasyedioglu. S, Pre-Service Elementary School Teachers' Learning Style and Attitudes toward Mathematics, Eurasia Journal of Mathematics, Science \& Technology Education, vol. 1, pp. 21-26.

[12] A. Suprijono, Cooperative Learning, Yogyakarta: Pustaka Pelajar, 2014, pp. 46.

[13] I. Kurniasih \& B. Sani, Ragam Pengembangan Model Pembelajaran untuk Meningkatkan Profesionalitas Guru, Jakarta: Kata Pena, 2015, pp. 71-72.

[14] T. Taniredja, ett. All, Model-model Pembelajaran Indonatif dan Efektif, Bandung: Penerbit Alfabeta, 2014, pp. 76-77

[15] M. A. Karafkan and Z. Aghazadeh, Investigating the Effects of Group Investigation (GI) and Cooperative Integrated Reading and Comprehension (CIRC) as the Cooperative Learning Techniques on Learner's Reading Comprehension, International Journal of Applied Linguistics \& English Literature, 2015, Vol. 4 No. 6.

[16] Retno, E.W, Pengembangan Model Pembelajaran Group Investigation Berbantu Video Camtasia Pada Materi Peluang Untuk Siswa SMA/MA Negeri Kabupaten Cilacap Tahun Pelajaran 2013/2014, Surakarta: Universitas Sebelas Maret, 2014.

[17] M. Hosnan, Pendekatan Saintifik dan Kontekstual dalam Pembelajaran Abad 21, Bogor: Penerbit Ghalia Indonesia, 2014, pp. 32. 